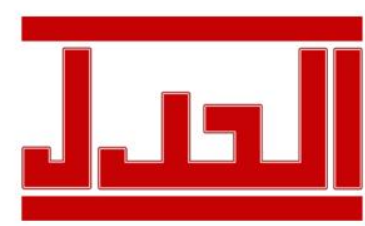

ISSN: $1979-4940$

E-ISSN : 2477-0124
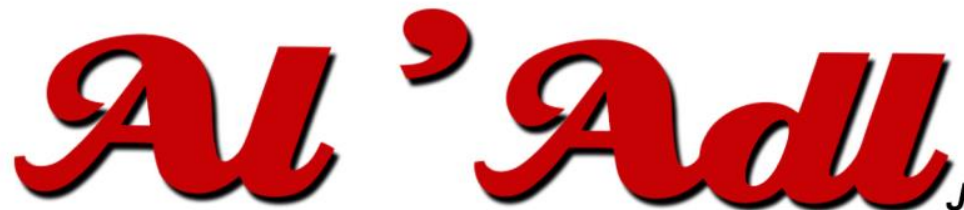

Jurnal Hukum

Editorial Office: Faculty of Law, Islamic University Of Kalimantan,

Jalan Adhyaksa No. 2 Kayutangi Banjarmasin, Kalimantan Selatan, Indonesia (70123)

Email: al_adl@uniska-bjm.ac.id

Web: http://ojs.uniska-bjm.ac.id

\section{FUNGSI PENILAIAN INSTRUMEN AKREDITASI BAGI INSTITUSI PERGURUAN TINGGI BARU}

\author{
Muhammad Rashif Anshari \\ Politeknik Unggulan Kalimantan \\ Jl. Pangeran Hidayatullah. Komplek Upik Futsal, RT 14 Banua Anyar, Banjarmasin Timur \\ Kota Banjarmasin, 70122 \\ E-mail: asip19881oud@ gmail.com
}

Submitted

Revised

Accepted

Published
: 17 Juni 2020
: 05 Juni 2021
: 02 Januari 2021
: 25 Juni 2021

\begin{abstract}
Das Sollen (law in book) Regulation of the Minister of Education and Culture Number 05 of 2020 has replaced the Regulation of the Minister of Research, Technology and Higher Education Number 32 of 2016 concerning Accreditation of Study Programs and Higher Education. However, amendments to the Legislation at the Ministry level do not fully accommodate aspects of legal justice, legal certainty and legal benefits in implementing the principles of Good Governance.

In the provisions of article 7 paragraph (2) of the Regulation of the Minister of Education and Culture Number 05 of 2020 explains that in the event that the re-accreditation rating by BAN-PT as referred to in paragraph (1) still gets Accreditation with the same rank, the Study Programs and Universities can only propose re-accreditation back to BAN-PT within 2 (two) years after obtaining the re-accreditation rating. this is in line with the provisions of article 4 paragraph (3) with the Regulation of the Minister of Research Technology and Higher Education Number 32 of 2016 which has been revoked, that the minimum accreditation as referred to in paragraph (1) is valid for a maximum of 2 (two) years. Technically and pragmatically the contents of the provisions of Article 7 paragraph (2) of the Regulation of the Ministry of Education and Culture Number 05 of 2020 seem discriminatory, especially for New Higher Education.

In the concrete level of "Das Sein" (Law In Action) a university is required to refer to the National Higher Education Standards, based on the National Higher Education Standards, newly established universities cannot graduate students within a period of 2 (two) years at the beginning of the establishment permit. , while the implementing regulations for accreditation issued by the National Accreditation Board for Higher Education (BAN-PT) in BAN-PT Regulation number 01 of 2020 concerning the Accreditation Mechanism and BAN-PT Regulation number 03 of 2019 Higher Education Accreditation Instruments, in general that the implementation of Higher Education accreditation using 9 Criteria. The Assessment of Weights on Criterion 3 Students and Criterion 9 Outcomes and Achievements of Tridharma is a source of fundamental problems that have an impact on New Higher Education.

According to the general principles of good governance (good governance). The role of the government as the implementer of laws and regulations as well as the organizer of political interaction through the regulations it makes becomes a benchmark for the public's view as a legal object for a good government system, every regulation that is stipulated will certainly become a policy and legal product that is binding.

Ideally, the Government (Ministry of Education and Culture) or the Accreditation Institute (BAN-PT) has a clear formulation regarding more technical implementing rules related to Accreditation for New Universities that lead to the achievement of aspects of justice, certainty and legal benefits in order to implement the principles of Good Governance.
\end{abstract}

The method used in this study is normative, namely by juxtaposing and analyzing policies in the form of 
laws and regulations with applicable legal theories and principles.

Keywords: Assessment, Instrument Accreditation, New College Institution

\begin{abstract}
Abstrak
Secara Das Sollen (law in book) Peraturan Menteri Pendidikan dan Kebudayan Nomor 05 Tahun 2020 telah mengganti Peraturan Menteri Riset Teknologi dan Pendidikan Tinggi No 32 Tahun 2016 tentang Akreditasi Program Studi dan Perguruan Tinggi. Akan tetapi Amandemen Peraturan Perundan-Undangan ditingkat Kementerian tidak secara menyeluruh mengakomodir aspek keadilan hukum, kepastian hukum dan kemanfaatan hukum dalam penerapan asas Good Governance.

Dalam ketentuan Pasal 7 Ayat (2) Peraturan Menteri Pendidikan dan Kebudayaan Nomor 05 Tahun 2020 menjelaskan bahwa Dalam hal peringkat Akreditasi ulang oleh BAN-PT sebagaimana dimaksud pada Ayat (1) tetap mendapatkan Akreditasi dengan peringkat yang sama maka Program Studi dan Perguruan Tinggi baru dapat mengusulkan Akreditasi ulang kembali ke BAN-PT dalam waktu 2 (dua) tahun sejak mendapatkan penetapan peringkat Akreditasi ulang. hal tersebut senafas dengan ketentuan isi Pasal 4 Ayat (3) dengan Peraturan Menteri Riset Teknologi dan Pendidikan Tinggi No 32 Tahun 2016 yang sudah dicabut, bahwa Akreditasi minimum sebagaimana dimaksud pada Ayat (1) berlaku paling lama 2 (dua) tahun. Secara teknis dan pragmatis isi dari ketentuan Pasal 7 Ayat (2) Peraturan Kementerian Pendidikan dan Kebudayaan Nomor 05 Tahun 2020 terkesan diskriminatif, khususnya bagi Perguruan Tinggi Baru.

Dalam tataran konkrit "Das Sein" (Law In Action) Sebuah Perguruan Tinggi wajib mengacu kepada Standar Nasional Pendidikan Tinggi, Berdasarkan Standar Nasional Pendidikan Tinggi, Perguran Tinggi yang baru berdiri belum bisa meluluskan mahasiswa dalam jangka waktu 2 (dua) tahun pada awal izin berdirinya, sedangkan aturan pelaksana akreditasi yang dikeluarkan Badan Akreditasi Nasional Perguruan Tinggi (BAN-PT) dalam Peraturan BAN-PT Nomor 01 Tahun 2020 tentang Mekanisme Akreditasi dan Peraturan BAN-PT Nomor 03 Tahun 2019 Instrumen Akreditasi Perguruan Tinggi, secara umum bahwa pelaksanaan akreditasi Perguruan Tinggi menggunakan 9 Kriteria. Penilaian Bobot pada Kriteria 3 Mahasiswa dan Kriteria 9 Luaran dan Capaian Tridharma menjadi sumber permasalahan mendasar yang berdampak pada Perguruan Tinggi Baru.

Menurut asas umum pemerintahan yang baik (good governance). Peran pemerintah sebagai pelaksana Peraturan Perundang-Undangan serta penyelenggara interaksi politik melalui regulasi yang dibuatnya menjadi tolok ukur terhadap pandangan masyarakat sebagai objek hukum terhadap sistem pemerintahan yang baik, setiap regulasi yang ditetapkan tentu menjadi sebuah kebijakan dan produk hukum yang bersifat mengikat.

Idealnya Pemerintah (Kementerian Pendidikan dan Kebudayaan) ataupun Lembaga Akreditasi (BANPT) memiliki formulasi yang jelas terkait aturan pelaksana yang lebih teknis terkait Akreditasi bagi Perguruan Tinggi Baru yang mengarah kepada tercapainya aspek keadilan, kepastian dan kemanfaatan hukum agar terlaksananya asas Good Gorvernance.

Metode yang digunakan dalam penelitian ini bersifat Normatif, yaitu dengan menyandingkan serta menganalisis Kebijakan berupa Peraturan Perundang-Undangan dengan teori dan asas hukum yang berlaku.
\end{abstract}

Kata kunci: Penilaian, Akreditasi, Perguruan Tinggi Baru.

\title{
PENDAHULUAN
}

Ketentuan diadakanya Undang-Undang Dasar merupakan suatu keharusan bagi suatu negara untuk menjamin hukum dasar (Ground Norm) yang melandasi segala aspek kehidupan berbangsa dan bernegaranya. Segala penyelenggaraan negara dan tindakan penyelenggara negara harus didasarkan pada ketentuan umum dasar. Demikian pula setiap pelaksanaan kehidupan kenegaraan yang dilakukan oleh pemerintah maupun rakyat atau warganegara, harus berdasarkan pada segala ketentuan yang ada dalam hukum dasar negara yaitu Pancasila dan Undang-Undang Dasar Negara Republik Indonesia Tahun 1945. 
Di dalam alinea keempat Pembukaan Undang-Undang Dasar Negara Republik Indonesia Tahun 1945 secara garis besar berisi tentang tujuan yang ingin dicapai bangsa Indonesia. Di dalamnya mencantumkan butir-butir Pancasila sebagai satu kesatuan yang utuh sebagai ideologi negara, sehingga unsur-unsur serta konsep tujuan dari berbangsa dan bernegara yang terkandung didalamnya yaitu melindungi, memajukan, mencerdaskan kehidupan bangsa dan melaksanakan ketertiban dunia yang berdasarkan kemerdekaan, perdamaian abadi dan keadilan sosial dapat terlaksana dan tercapai sebagaimana mestinya.

Beberapa tujuan yang tercantum didalam Pembukaan Undang-Undang Dasar Negara Republik Indonesia Tahun 1945, salah satunya adalah pendidikan. Adanya Pendidikan Nasional berfungsi untuk mengembangkan kemampuan serta meningkatkan mutu kehidupan dan martabat manusia Indonesia dalam rangka upaya mewujudkan tujuan nasional. Pendidikan adalah usaha sadar dan terencana untuk mewujudkan suasana belajar dan proses pembelajaran agar peserta didik secara aktif mengembangkan potensi dirinya untuk memiliki pengembangan spiritual keagamaan, pengendalian diri, kepribadian, kecerdasan, akhlak mulia, serta keterampilan yang diperlukan dirinya, masyarakat, bangsa dan negara. ${ }^{1}$ Hal ini karena pendidikan merupakan komponen penting dalam kehidupan untuk mencapai kesejahteraan.

Makna pendidikan dalam Pembukaan Undang-Undang Dasar Negara Republik Indonesia Tahun 1945 disebutkan sebagai konsep 'untuk mencerdaskan kehidupan bangsa'. Konsep mencerdaskan kehidupan bangsa dipilih karena memiliki makna yang sangat luas dan mendasar. Makna dari cerdas sendiri dapat dipahami sebagai kesadaran, integritas, tanggung jawab atau bisa juga berarti tidak mudah dibodoh-bodohi. Meskipun makna "mencerdaskan kehidupan bangsa" tidak hanya berupa pendidikan, tetapi sangat kental dengan nilai edukasi pembelajaran yang dapat membuat bangsa menjadi cerdas melalui sistem pendidikan.

Di dalam batang tubuh Undang-Undang Dasar Negara Republik Indonesia Tahun 1945 Bab XIII tentang Pendidikan dan Kebudayaan pada Pasal 31 Ayat (1) sampai dengan Ayat (5) menjelaskan bahwa setip warga negara Indonesia berhak mendapatkan pedidikan yang baik dan layak. Hal ini merupakan wujud dari amanat konstitusi yang memberikan dan menjamin hak pendidikan kepada seluruh masyarakat.

Sistem Pendidikan Nasional mengatur dan menjamin pemenehuan hak terhadap seluruh warga negara Indonesia untuk dapat memperoleh pendidikan sesuai dengan keinginan Undang-Undang Dasar Negara Republik Indonesia Tahun 1945, mulai dari tingkat dasar

\footnotetext{
${ }^{1}$ Pasal 1, Undang-Undang Nomor 20 Tahun 2003 tentang Sistem Pendidikan Nasional.
} 
hingga tingkat pendidikan tinggi. Meskipun dalam implementasinya kebijakan pemerintah tentang Sistem Pendidikan yang diatur dalam Peraturan Perundang-Undangan masih belum berjalan tepat sasaran dan maksimal.

Pengaturan tentang Pendidikan Tinggi di dalam Sistem Pendidikan Nasional diatur dalam Undang-Undang Nomor 12 Tahun 2012 tentang Pendidikan Tinggi dengan kebijakan pelaksanaan pada Peraturan Pemerintah Nomor 4 Tahun 2014 tentang Penyelenggaraan Pendidikan Tinggi dan Pengelolaan Institusi Perguruan Tinggi sebagai acuan dan pedoman dasar terlaksananya sebuah sistem Pendidikan Tinggi di Indonesia.

Pengelolaan Perguruan Tinggi adalah kegiatan pelaksanaan jalur, jenjang, dan jenis Pendidikan Tinggi melalui pendirian Perguruan Tinggi oleh Pemerintah dan/atau Badan Penyelenggara untuk mencapai tujuan Pendidikan Tinggi. ${ }^{2}$ Pengelolaan Institusi Perguruan Tinggi haruslah memenuhi segala bentuk standar, syarat dan dasar yang berpedoman pada Peraturan Perundang-Undangan yang mengaturnya, dari ketentuan ini lah yang menjadikan suatu Perguruan Tinggi dapat melaksanakan Sistem Pendidikan Nasional yang baik.

Dalam pengelolaan Institusi Perguruan Tinggi, Standar Nasional Perguruan Tinggi (SN Dikti) mengamanatkan tugas dan fungsi Tridharma Peguruan Tinggi yaitu Pendidikan, Penelitian dan Pengabdian kepada Masyarakat selain itu, Institusi Perguruan Tinggi juga diwajib melaporkan hasil capaian Tri Dhrama tersebut melalui kegiatan penilaian untuk menentukan kelayakan Program Studi dan Institusi Perguruan Tinggi dalam bentuk akreditasi sesuai dengan ketentuan Peraturan Menteri Pendidikan dan Kebudayan Nomor 05 Tahun 2020 Tentang Akreditasi Program Studi dan Institusi Perguruan Tinggi. Karena dengan ini diharapkan suatu Institusi Perguruan Tinggi dapat menjaga dan meningkatkan kualitas Sistem Pendidikan Tinggi sesuai dengan Standar Nasional Pendidikan Tinggi berdasarkan Tridharma Perguruan Tinggi, melalui pengawasan dan evaluasi yang dilakukan Badan Akreditasi Nasional Perguruan Tinggi.

Bagi Institusi Perguruan Tinggi baru, akreditasi perdana merupakan hal yang sulit. BAN-PT sebagai lembaga akreditasi mengatur sistem dan mekanisme akreditasi yang diatur didalam Peraturan BAN-PT Nomor 01 Tahun 2020 tentang Mekanisme Akreditasi Untuk Akreditasi Yang Dilakukan Oleh BAN-PT mempersyaratkan 9 Kriteria dalam bobot penilaian akreditasi menjadi problematika yang mendasar. Penilaian akreditasi yang dapat dinilai secara penuh hanya 7 (Tujuh) kriteria saja, itu pun dengan persyaratan pemenuhan

2 Pasal 2 Peraturan Pemerintah Nomor 4 Tahun 2014 Tentang Penyelenggaraan Pendidikan Tinggi dan Pengelolaan Institusi Perguruan Tinggi. 
tenaga dosen, sarana prasarana, tata pamong dan lain-lain. Dengan belum adanya mahasiswa/lulusan pada kriteria 3 dan Luaran \& Capaian Tridharma. Pada kriteria 9 bukan berarti Instrumen Akreditasi tentang mahasiswa, lulusan dan Luaran dan Capaian Tridharma tidak ada penilaian dan tidak optimal, karena Institusi Perguruan Tinggi baru belum memiliki lulusan/alumni dan luaran terkait lulsan yang dapat dimasukan kedalam perhitungan bobot penilaian.

Dalam ketentuan Pasal 7 Ayat (2) Peraturan Menteri Pendidikan dan Kebudayaan Nomor 05 Tahun 2020 menjelaskan bahwa Dalam hal peringkat Akreditasi ulang oleh BANPT sebagaimana dimaksud pada Ayat (1) tetap mendapatkan Akreditasi dengan peringkat yang sama maka Program Studi dan Perguruan Tinggi baru dapat mengusulkan Akreditasi ulang kembali ke BAN-PT dalam waktu 2 (dua) tahun sejak mendapatkan penetapan peringkat Akreditasi ulang, ketentuan ini merupakan problematika terhadap regulasi yang mendasar, karena suatu Institusi Perguruan Tinggi Baru tidak bisa meluluskan mahasiswa dalam jangka waktu 2 (dua) tahun pada awal izin berdirinya di terbitkan. Hal ini karena adanya batasan SKS yang harus dipenuhi sebelum kelulusan.

Dalam instrumen penilaian akreditasi Badan Akreditasi Nasional (BAN-PT), di dalam Kriteria 3 (tiga) yang berisikan deskriptor tentang mahasiswa dan lulusan Perguruan Tinggi secara otomatis akan terhambat karena matriks penilaian terhadap lulusan belum dapat tercapai atau nihil.

Kebijakan ini terkesan mendikriminasi Pengelola Perguruan Tinggi Baru, karena dampaknya dianggap besar terhadap Institusi Perguruan Tinggi itu sendiri, mahasiswa, lulusan dan para user/pengguna lulusan (stakeholders).

Problematika ini juga menjadi beban moral bagi penyelenggara Institusi Perguruan Tinggi sebagai penanggung jawab peserta didik. Sehingga upaya maksimal dalam penerapan Tridharma Perguruan Tinggi yang diamanatkan Undang-Undang Dasar tidak sesuai dengan penilaian dari kebijakan yang mengaturnya.

Berdasarkan pemaparan diatas, dijelaskan bahwa kebijakan yang diatur dan ditetapkan oleh pemerintah memiliki kesenjangan dengan teori hukum, khusunya dalam bentuk efektifitas yang menjadi objek kajian kebijakan pemerintah terhadap efektifitas hukum dan teori keadilan dan efektifitas didalam hukum.

Dalam definisi teori, keadilan hanya dapat dapat muncul berdasarkan ketentuan hukum positif berupa undang undang yang ditentukan secara obyektif. Tata aturan ini adalah hukum 
positif. Inilah yang dapat menjadi objek ilmu, bukan hukum secara metafisik. ${ }^{3}$ Sehingga dirasa perlu untuk mengkaji lebih dalam tentang kebijakan yang berkaitan terhadap keberlangsungan Sistem Pendidikan Nasional yang adil dan berkesinambungan. Dengan menggunakan teori hukum dan asas-asas hukum untuk memaparkan kembali fungsi dari Pendidikan Tinggi sebagai upaya mencerdaskan kehidupan bangsa.

\section{RUMUSAN MASALAH}

Berdasarkan latar belakang masalah diatas, maka dapat dirumuskan suatu rumusan masalah yang akan diteliti yaitu sebagai berikut:

1. Bagaimana aspek hukum dalam sistem penilaian akreditasi bagi Institusi Perguruan Tinggi?

2. Bagaimana kebijakan tentang sistem penilaian akreditasi bagi Institusi Perguruan Tinggi Baru?

\section{METODE PENELITIAN}

Dalam pembuatan sebuah karya ilmiah terutama karya ilmiah penelitian hukum diharuskan menggunakan metode penelitian hukum. Ilmu hukum berusaha untuk menampilkan hukum secara integral sesuai dengan kebutuhan kajian ilmu hukum itu sendiri, sehingga metode penelitian dibutuhkan untuk memperoleh arah penelitian yang komprehensif. ${ }^{4}$ Metode yang digunakan dalam artikel ini bersifat Normatif, yaitu dengan meneliti bahan pustaka atau bahan hukum (data sekunder) dan menganalisis Kebijakan dengan pendekatan Peraturan Perundang-undangangan (statute approach) dengan menggunakan teori dan asas hukum yang berlaku dan berkaitan untuk menemukan ProblemIdentification dan Problem-Solution.

\section{PEMBAHASAN}

\section{A. Aspek Hukum Dalam Penilaian Akreditasi Perguruan Tinggi}

Aspek hukum adalah keseluruhan peraturan baik yang tertulis maupun tidak tertulis yang mengatur tata tertib di dalam masyarakat dan terhadap pelanggarnya

3 Jimly Asshiddiqie (2006), Teori Hans Kelsen tentang Hukum, Sekretariat Jenderal Mahkamah Konstitusi, Jakarta, hlm. 22.

${ }^{4}$ Yati Nurhayati, "Perdebatan Metode Normatif dengan Metode Empirik Dalam Penelitian Ilmu Hukum Ditinjau Dari Karakter, Fungsi dan Tujuan Ilmu Hukum”, Jurnal Al Adl, Volume 5 Npmor 10, 2013, hlm. 15. 
umumnya dikenakan sanksi. Hukum memiliki beberapa unsur, yaitu, adanya peraturan atau ketentuan yang memaksa dan mengikat, berbentuk tertulis maupun tidak tertulis, mengatur kehidupan masyarakat, memiliki sanksi.

Sebagai bagian dari aspek hukum tertulis setiap kebijakan publik perlu disusun secara komprehensif, selain perlu pertimbangan yang mendasar juga harus memenuhi konsep asas kepastian, keadilan dan kemanfaatan hukum.

1. Kepastian Hukum

Salah satu aspek dari asas kepastian hukum adalah penegakan hukum. Peran yang komprehensif dari aparat penegak hukum tidak dapat di biarkan begitu saja. ${ }^{5}$ Dalam hal kepastian hukum ini menurut Teubner, ${ }^{6}$ hukum yang dapat memuaskan semua pihak adalah hukum yang responshif dan hanya lahir jika ada demokratisasi legislasi. Kepastian Hukum menekankan agar hukum atau peraturan itu ditegakkan sebagaimana yang diinginkan oleh bunyi hukum/peraturannya. ${ }^{7}$ Hukum hanya sebagai legitimasi keinginan pemerintah, dalam kondisi seperti itu ada tindakan pemerintah dianggap bertentangan dengan hukum. Kepentingan-kepentingan masyarakat menjadi terabaikan karena hukum bersifat mandiri karena makna-maknanya mengacu pada dirinya sendiri (keadilan, kepastian, kemanfaatan).

2. Keadilan

John Rawls berpendapat bahwa keadilan itu merupakan fokus utama dari sistem hukum dan keadilan tidak dapat dikorbankan karena ada dua prinsip jika lihat bukunya,

pertama;each person is to have and equal right to the most extensive basic liberty compatible with a smiliar liberty for others. Kedua; social and economic inequalities are to be arranged so they are both a, reasonably expected to be everyone advantage and, $b$. attached to positons and offices open to all. ${ }^{8}$

Keadilan merupakan salah satu tujuan hukum yang paling banyak dibicarakan sepanjang perjalanan sejarah filsafat hukum. ${ }^{9}$

\footnotetext{
5 Suwardi Sagama, (2016). Analisis Konsep Keadilan, Kepastian Hukum Dan Kemanfaatan Dalam Pengelolaan Lingkungan,. Jurnal Pemikiran Hukum Islam. Vol 15 (1), 20-41

${ }^{6}$ Gunther Teubner, (2012) Subtantive and Reflexsive Elements in Modern Law, Law and Social Review, Volume 17 Nomor 2. Dikutip oleh Teguh Prasetyo dan Abdul Halim Barkatullah, Filsafat, Teori, dan Ilmu Hukum, Jakarta: Raja Grafindo, h. 317-318.

7 Sulardi (2015), Kepastian Hukum, Kemanfaatan dan Keadilan Terhadap Perkara Pidana Anak (Kajian Putusan Nomor 201/Pid.Sus/2014/PN/Bly). Jurnal Yudisial, Vol 8 (3), 251-268

${ }^{8}$ John Rawls, (1971) A Theory of Justice, , Cambridge, Massachusetts, USA: Harvad University Press, Hlm 60.

9 Dardji Darmohardjo, Shidarta.,(2006) Pokok-pokok filsafat hukum: apa dan bagaimana filsafat hukum Indonesia, Jakarta: Gramedia Pustaka Utama, hlm.155.
} 
3. Kemanfaatan

Kemanfaatan merupakan hal yang paling utama didalam sebuah tujuan hukum, mengenai pembahasan tujuan hukum terlebih dahulu diketahui apakah yang diartikan dengan tujuannya sendiri dan yang mempunyai tujuan hanyalah manusia akan tetapi hukum bukanlah tujuan manusia, hukum hanyalah salah satu alat untuk mencapai tujuan dalam hidup bermasyarakat dan bernegara. ${ }^{10}$ Tujuan hukum bisa terlihat dalam fungsinya sebagai fungsi perlindungan kepentingan manusia, hukum mempunyai sasaran yang hendak dicapai. ${ }^{11}$ Jika kita lihat defenisi manfaat dalam kamus besar bahasa Indonesia manfaat secara terminologi bisa diartikan guna atau faedah. ${ }^{12}$

Aspek hukum dalam penilaian akreditasi adalah segala kebijakan berupa peraturan tertulis maupun tidak tertulis yang mengatur tentang penilaian akreditasi Perguruan Tinggi di Indonesia. Kebijakan induk dalam aspek hukum yaitu UndangUndang Nomor 20 Tahun 2003 tentang Sistem Pendidikan Nasional yang kemudian dijalankan berdasarkan Peraturan Perundang-Undangan yang mengaturnya yaitu Peraturan Menteri Riset Teknologi dan Pendidikan Tinggi Nomor 32 Tahun 2016 tentang Akreditasi Program Studi dan Perguruan Tinggi.

Akreditasi institusi perguruan tinggi adalah proses penilaian terhadap institusi secara keseluruhan untuk mengetahui komitmen institusi terhadap kapasitas institusi dan efektivitas pendidikan, yang didasarkan pada standar akreditasi yang telah ditetapkan. Akreditasi dilakukan oleh BAN-PT terhadap semua perguruan tinggi di Indonesia. ${ }^{13}$

Akuntabilitas penyelenggaraan pendidikan sangat penting, sehingga lembaga pendidikan terkait wajib untuk mempertanggungjawabkan mutunya kepada masyarakat khususnya stakeholder terkait. ${ }^{14}$

Menurut Chittenden (1994) mengemukakan tujuan penilaian (assessment purpose) adalah "keeping track, checking-up, finding-out, and summing-up" yaitu: ${ }^{15}$

1. Keeping track, yaitu untuk menelusuri dan melacak proses belajar peserta didik sesuai dengan rencana pelaksanaan pembelajaran yang telah ditetapkan. Untuk itu, guru harus mengumpulkan data dan informasi dalam kurun waktu tertentu melalui berbagai

\footnotetext{
${ }^{10}$ M. Ridwansyah, (2016). Mewujudkan Keadilan, Kepastian dan Kemanfaatan Hukum dalam Qanun Bendera dan Lambang Aceh, Jurnal Konstitusi, Vol 13 (2). 278-298.

${ }^{11}$ Said Sampara dkk, Pengantar Ilmu Hukum, Yogyakarta : Total Media, 2011. hlm. 40.

${ }_{12} \mathrm{KBBI}$, http://kbbi.web.id/manfaat, (diakses tanggal 09 Januari 2019).

${ }^{13}$ Buku III Borang AIPT, (2011), hlm. 2.

${ }^{14}$ Y Yulianingsih, (2015). Manajemen Akreditasi Program Studi Pada Perguruan Tinggi. Al-Idarah: Jurnal Kependidikan Islam. Vol 5.

${ }^{15}$ Arifin Zainal (2009), Evaluasi pembelajaran, Bandung: Remaja Rosdakarya, hlm. 15.
} 
jenis dan teknik penilaian untuk memperoleh gambaran tentang pencapaian kemajuan belajar peserta didik.

2. Checking-up, yaitu untuk mengecek ketercapaian kemampuan peserta didik dalam proses pembelajaran dan kekurangan-kekurangan peserta didik selama mengikuti proses pembelajaran. Dengan kata lain, guru perlu melakukan penilaian untuk mengetahui bagian mana dari materi yang sudah dikuasai peserta didik dan bagian mana dari materi yang belum dikuasai;

3. Finding-out, yaitu untuk mencari, menemukan dan mendeteksi kekurangan kesalahan atau kelemahan peserta didik dalam proses pembelajaran, sehingga guru dapat dengan cepat mencari alternatif solusinya.

4. Summing-up, yaitu untuk menyimpulkan tingkat penguasaan peserta didik terhadap kompetensi yang telah ditetapkan. Hasil penyimpulan ini dapat digunakan guru untuk menyusun laporan kemajuan belajar berbagai pihak yang berkepentingan.

Setiap aspek hukum yang berjalan beriringan dengan regulasi yang mengaturnya merupakan bentuk campur tangan pemerintah yang harus didasarkan pada peraturan perundang-undangan yang berlaku sebagai perwujudan dari asas kepastian, keadilan dan kemanfaatan yang menjadi sendi utama negara hukum.

Sejak dianutnya konsepsi welfare state, yang menempatkan pemerintah sebagai pihak yang bertanggung jawab terhadap kesejahteraan umum warga negara dan untuk mewujudkan kesejahteraan ini pemerintah diberi wewenang untuk campur tangan dalam segala lapangan kehidupan masyarakat, yang dalam campur tangan ini tidak saja berdasarkan pada peraturan perundang-undangan, tetapi dalam keadaan tertentu dapat bertindak tanpa bersandar pada peraturan perundang-undangan, tetapi berdasar pada inisiatif sendiri. Namun, disatu sisi keaktifan pemerintah dalam mengupayakan kesejahteraan umum haruslah senantiasa berdasarkan pada asas-asas umum pemerintahan yang baik (Good Governance). ${ }^{16}$

\section{B. Kebijakan Tentang Sistem Penilaian Akreditasi Bagi Institusi Perguruan Tinggi Baru.}

Akreditasi merupakan sebuah pengakuan terhadap perguruan tinggi atau program studi yang menunjukkan bahwa Perguruan Tinggi atau Program Studi tersebut melaksanakan progaram pendidikan dan mutu lulusan yang dihasilkan, telah memenuhi

\footnotetext{
${ }^{16}$ Ridwan HR, (2014) Hukum Administrasi Negara PT RajaGrafindo Persada, Jakarta. hlm. 21.
} 
standar yang ditetapkan Badan Akreditasi Nasional Perguruan Tinggi (BAN-PT). ${ }^{17}$ Akreditasi diumpamakan sebagai "ruh" bagi Program Studi dan Institusi Pendidikan Tinggi di Indonesia. Tanpa akreditasi prodi tidak diijinkan berdiri dan mulai 2019 institusi tanpa akreditasi tidak bisa beroprasi. ${ }^{18}$

Dalam Pasal 86 Ayat (3) Peraturan Pemerintah Nomor 19 Tahun 2005 tentang Standar Nasional Pendidikan disebutkan bahwa:

"Akreditasi sebagaimana dimaksud pada Ayat (1) dan Ayat (2) sebagai bentuk akuntabilitas kepada publik dilakukan secara obyektif, adil, transparan, dan komprehensif dengan menggunakan instrumen dan kriteria yang mengacu kepada Standar Nasional Pendidikan”.

Keputusan mengenai mutu didasarkan pada evaluasi dan penilaian terhadap berbagai bukti yang terkait dengan standar yang ditetapkan dan berdasarkan nalar dan pertimbangan para pakar sejawat. Bukti-bukti yang diperlukan termasuk laporan tertulis yang disiapkan oleh institusi perguruan tinggi yang diakreditasi, diverifikasi dan divalidasi melalui kunjungan atau asesmen lapangan tim asesor ke lokasi perguruan tinggi. ${ }^{19}$

Selain menentukan kelayakan program studi dan Institusi Perguruan Tinggi akreditasi juga bertujuan untuk menjamin mutu secera eksternal baik bidang akademik maupun non akademik berlandaskan asas independen, akurat, objektif, transparan dan akuntabel. Status akreditasi Perguruan Tinggi menjadi perhatian masyarakat dalam menggambarkan mutu, relevansi dan efisiensi. ${ }^{20}$

Dalam rangka mewujudkan akuntabilitas publik, perguruan tinggi harus secara aktif membangun sistem penjaminan mutu internal. Untuk membuktikan bahwa sistem penjaminan mutu internal telah dilaksanakan dengan baik dan benar, perguruan tinggi harus diakreditasi oleh lembaga penjaminan mutu eksternal. Dengan sistem penjaminan mutu yang baik dan benar, perguruan tinggi akan mampu meningkatkan mutu, menegakkan otonomi, dan mengembangkan diri sebagai institusi akademik dan kekuatan moral masyarakat secara berkelanjutan. Hal ini menunjukkan bahwa Perguruan Tinggi

\footnotetext{
${ }^{17}$ Bahri, K., \& Rahmadiane, G.D (2017). Pengaruh Presepsi, Akreditasi Prodi, Dan Promosi Terhadap Keputusan Memilih Studi Akuntansi Pada Politeknik Harapan Bersama. Jurnal Inspirasi Bisnis dan Manajemen. Vol 1(2), 145-158 Retrieved from Http://jurnal.unswagati.ac.id/index.php/jibm

${ }_{18}$ Sururin (2017). "Peta Peringkat Akreditasi Perguruan Tinggi Keagamaan Islam. Sebuah kajian awal”. Jurnal At -Taqaddum. Vol 9(1), 95-112.

${ }^{19}$ Buku I Naskah Akademik AIPT, 2011, hlm. 5.

${ }^{20}$ C.F. Sekarningsih dan A. (2019). Peranan Pengelolaan Arsip Sebagai Pendukung Akreditasi BANPT di Program Studi S-1 Pendidikan Biologi Fakultas Matematika dan IPA Universitas Negeri Semarang (Studi Kasus Tahun 2015), Jurnal Ilmu Perpustakaan, pp 1-12.
} 
yang sudah terakreditasi mendapat pengakuan yang lebih besar di masyarakat dibandingkan dengan Perguruan Tinggi yang berlum terakreditasi. ${ }^{21}$

Berdasarkan peraturan perundang-undangan yang berlaku dan berbagai pertimbangan tersebut di atas, BAN-PT melakukan akreditasi bagi semua institusi perguruan tinggi di Indonesia. Akreditasi institusi perguruan tinggi adalah proses evaluasi dan penilaian secara komprehensif atas komitmen perguruan tinggi terhadap mutu dan kapasitas penyelenggaraan program tridarma perguruan tinggi, untuk menentukan kelayakan program dan satuan pendidikan. Komitmen tersebut dijabarkan ke dalam sejumlah standar akreditasi. ${ }^{22}$

Kriteria penilaian borang atau instrumen akreditasi Institusi Perguruan Tinggi ditujukan kepada tingkat komitmen terhadap kapasitas institusi dan keefektifan pendidikan Institusi Perguruan Tinggi yang dijabarkan menjadi tujuh standar akreditasi. Di dalam borang Institusi Perguruan Tinggi, setiap standar dirinci menjadi sejumlah elemen/butir yang harus ditunjukkan yang disajikan harus mencerminkan proses dan pencapaian mutu penyelenggaraan program Perguruan Tinggi dibandingkan dengan target yang telah ditetapkan. Analisis tersebut harus didasarkan atas evaluasi diri.

Mekanisme penyusunan akreditasi berdasarkan tahapan akreditasi yaitu evaluasi data dan informasi, penetapan status akreditasi dan peringkat terakreditasi serta pemantauan dan evaluasi. Keputusan mengenai mutu didasarkan pada evaluasi dan penilaian terhadap berbagai bukti yang terkait dengan standar/kriteria yang ditetapkan. ${ }^{23}$

Akibat hukum dari adanya penilaian akreditasi perguruan tinggi berdasarkan capaian hasil yang menjadi sebuah rekomendasi kelayakan Perguruan Tinggi. Implementasi dari kebijakan akreditasi melalui BAN-PT melahirkan sebuah keputusan penilaian akhir, berdasarkan setiap standar dan atau elemen dalam borang institusi Perguruan Tinggi dinilai secara kuantitatif, menggunakan quality grade descriptor sebagai yaitu sangat baik, baik., cukup, kurang dan sangat kurang. ${ }^{24}$

Hasil akir dari proses akreditasi merupakan sebuah akibat hukum, karena rekomendasi hasil penilaian akreditasi yang dikeluarkan BAN-PT memiliki kekuatan hukum dan berdasar pada Peraturan Perundagan-Undangan.

21 Prasetyo. (2014). Dampak Kebijakan Akreditasi Perguruan Tinggi Terhadap Daya Saing (Competitiveness) Perguruan Tiggi Swasra Di Kabupaten Kebumen Jurnal Fokus Bisnis. Vol.13.

${ }^{22}$ Ibid.

${ }^{23}$ F.N. Nuphus. A Rahmatulloh, H. Sulastri (2019) Sistem Informasi Akreditasi Perguruan Tinggi (SIAP) untuk Pengisian Borang Standar 3 BAN-PT) Jurnal Sistem dan Teknlogi Informasi. Vol \& (2) 130-137.

${ }^{24}$ Ibid. 
Didalam BAB III Keputusan Penilaian Akreditasi Institusi Perguruan Tinggi Buku V Pedoman Penilaian Borang dan Evaluasi Diri Akreditasi Institus Perguruan Tinggi BAN-PT 2017, Hasil akreditasi perguruan tinggi dinyatakan sebagai Terakreditasi dan Tidak Terakreditasi. Perguruan tinggi yang terakreditasi diberi peringkat sebagai berikut:

1) A (Sangat Baik) dengan nilai akreditasi $361-400$

2) B (Baik) dengan nilai akreditasi $301-360$

3) $\mathrm{C}$ (Cukup) dengan nilai akreditasi $200-300$

4) Tidak Terakreditasi dengan nilai akreditasi kurang dari 200

Penentuan skor akhir merupakan jumlah dari hasil penilaian borang akreditasi perguruan tinggi (90\%) dan evaluasi diri perguruan tinggi (10\%). Adapun masa berlaku akreditasi institusi perguruan tinggi untuk semua peringkat akreditasi adalah 5 (lima) tahun.

Perguruan tinggi yang tidak terakreditasi dapat mengajukan usul untuk diakreditasi kembali setelah melakukan perbaikan-perbaikan yang berarti paling cepat satu tahun terhitung mulai tanggal surat keputusan penetapan status tidak terakreditasinya yang dikeluarkan oleh BAN-PT.

Akibat hukum dari adanya akreditasi perguruan tinggi berimplikasi pada unsur yang berkorelasi dalam lingkup penyelenggaran Pendidikan Tinggi tersebut. Dalam pelaksanaanya kebijakan BAN-PT tentang sistem akreditasi Perguruan Tinggi memunculkan implikasi yuridis yang secara langsung dan tidak langsung pada para pihak. Khususnya pihak yang secara hukum terikat didalam Peraturan Menteri Pendidikan dan Kebudayan Nomor 05 Tahun 2020 tentang Akreditasi Program Studi dan Perguruan Tinggi. Dan Pedoman Penilaian Instrumen Akreditasi BAN-PT.

Dalam tataran realitas atau dimensi kenyataan (das sein) penerapan akreditasi terhadap Institusi Perguruan Tinggi tidak semudah yang dipahami atau yang dibaca dalam buku teori. Setidaknya ada 3 (tiga) faktor general yang mempengaruhi pelaksanaan akreditasi perguruan tinggi yaitu:

1. Faktor Kematangan Institusi Perguruan Tinggi

Faktor kematangan merupakan faktor yang pasti dirasakan oleh semua Institusi Perguruan Tinggi negeri maupun swasta. kematangan atau kesiapan dalam menghadapi akreditasi adalah hal yang penting karena faktor ini langsung berhubungan dengan rangkaian proses akrediasi tersebut. Bagian dari faktor kesiapan adalah dokumen-dokumen akreditasi serta deskripsi diri Institusi Perguruan Tinggi, sarana prasarana dan sumber daya manusia dari unsur pimpinan hingga penjaga 
keamanan. Faktor kesiapan merupakan ketentuan dari isi instrumen akreditasi itu sendiri yang bersifat terperinci dengan penilaian yang sangat detail dan mendalam, serta komprehensif menggunakan asas transparansi dan dapat dipertanggung jawabkan. Kematangan tenaga dosen dan tenaga kependidikan adalah kunci penting. Saling bersinergis serta bekerjasama dalam unit kerja sangat penting untuk menunjang faktor kesiapan ini.

Faktor kesiapan Perguruan Tinggi juga merupakan modal penting dalam menjalani dan melewati proses assesmen lapangan dari asesor. Oleh karena itu faktor kematangan ini bisa di antisiapasi melalui pelatihan dan pengembangan terhadap kemampuan seluruh sivitas akademkia tentang mekanisme atau prosedur Akreditasi Perguruan Tinggi. faktor ini juga diantisipasi melalui pengalaman dosen/tenaga kependidikan yang sudah pernah merasakan proses Akreditasi sebelumnya. Namun hal tersebut sangat sulit bagi setiap Perguruan Tinggi yang baru pertama kali di Akreditasi, karena minimnya pengalaman dan masih belum optimal dalam persiapan.

2. Faktor Yayasan bagi Institusi Perguruan Tinggi Swasta / Non Negeri

Faktor yayasan merupakan faktor utama bagi keberlangsungan Institusi Perguruan Tinggi Swasta. Faktor inti ini diibaratkan jantung dari sebuah Institusi Perguruan Tinggi Swasta, karena yayasan atau badan hukum yang menaungani Perguruan Tinggi Swasta sebagai pilar utama dalam proses penyelenggaraan pendidikan di Perguruan Tinggi Swasta.

Yayasan memiliki fungsi sebagai Badan Penyelenggara Pendidikan Tinggi ${ }^{25}$ peran yayasan sebagai badan hukum penyelenggara perguruan tinggi swasta diatur didalam Undang-Undang Nomor 12 Tahun 2012 tentang Pendidikan Tinggi.

Sehingga Yayasan/Badan Penyelenggara yang memiliki komitmen yang baik pasti akan berbanding lurus dengan kualitas Institusi Perguruan Tinggi yang dinaunginya. Hal tersebut berkaitan dengan dukungan materiil maupun moril bagi institusi perguruan tinggi. Namun sebaliknya, yayasan yang tidak memiliki komitmen dengan Institusi Perguruan Tinggi yang dinaunginya, hal ini yang menjadi faktor penghambat bagi perkembangan institusi perguruan tinggi yang baik. Faktor yayasan juga dapat mempengaruhi faktor kesiapan institusi, hal ini karena peran dan tanggung jawab yayasan sebagai badan penyelenggara yang diatur oleh peraturan perundang -

${ }^{25}$ Peraturan Pemerintah Nomor 4 Tahun 2014 tentang Penyelenggaraan Pendidikan Dan Pengelolaan Perguruan Tinggi Pasal 1 Ayat (19). 
undangan di dalam struktur Insitusi Perguruan Tinggi Swasta. Pembinaan yayasan yang baik pasti berbanding lurus dengan pelaksanaan Pendidikan Tinggi pada PTS.

3. Faktor Kebijakan / Regulasi

Faktor kebijakan pemerintah merupakan faktor hilir yang paling mendasar, karena problematika ini terletak dalam tataran Peraturan Perundang-Undangan itu sendiri. meskipun faktor ini tidak begitu dirasakan bagi banyak Institusi Perguruan Tinggi, namun faktor ini sangat berdampak pada instiusi Perguruan Tinggi baru.

Seperti yang diatur di dalam ketentuan Pasal 7 Ayat (2) Peraturan Menteri Pendidikan dan Kebudayaan Nomor 05 Tahun 2020 menjelaskan bahwa dalam hal peringkat Akreditasi ulang oleh BAN-PT sebagaimana dimaksud pada Ayat (1) tetap mendapatkan Akreditasi dengan peringkat yang sama maka Program Studi dan Perguruan Tinggi baru dapat mengusulkan Akreditasi ulang kembali ke BAN-PT dalam waktu 2 (dua) tahun sejak mendapatkan penetapan peringkat Akreditasi ulang. Isi ketentuan merupakan bentuk faktor hilir yang dimaksud. Kententuan terkesan seperti mendiskriminasi dan menjadi permasalahan mendasar dalam tataran kebijakan bagi Institusi Perguruan Tinggi Baru, hal tersebut karena suatu Institusi Perguruan Tinggi secara aturan baku dalam Standar Nasional Pendidikan Tinggi, belum bisa meluluskan mahasiswa dalam tempo waktu 2 (dua) tahun pada awal izin berdirinya di terbitkan. Ditingkat strata 1 mapun diploma sekalipun, hal ini disebabkan karena terhalang oleh batasan SKS yang harus dipenuhi mahasiswa untuk dapat lulus.

Dalam proses akreditasi faktor ini menjadi penghalang bagi istitusi Perguruan Tinggi baru untuk mendapatkan nilai akreditasi maksimal. Karena hal yang kompleks di dalam kebijakan pemerintah menghasilkan problematika yang kompleks pula dalam pelaksanaanya. Di dalam Buku V Pedoman Penilaian Borang dan Evaluasi Diri AIPT BAN-PT, instrumen akreditasi Institusi Perguruan Tinggi memuat butir mahasiswa dan lulusan pada kriteria 3 (tiga).

Adanya bobot penilaian yang hilang, karena dasar kebijakan mengharuskan Institusi Perguruan Tinggi baru harus memutar otak untuk dapat mencapai hasil maksimal, khsusnya dalam bobot $13,16 \%$ presentase standar 3 (tiga) mahasiswa dan lulusan. Terdapatnya pengurangan komponen penilaian rasio jumlah lulusan atau alumni yang nihil, sehingga membuat penilaian yang mestinya sudah maksimal untuk memperoleh matriks penilaian terbaik menjadi gagal maksimal (Maximum Failed). 
Kebijakan yang mengharuskan membuat poin lulusan yang hilang menjadikan perhitungan yang timpang dalam proses penilaian akreditasi. Dalam hal ini Kebijakan yang dibuat pemerintah khususnya melalui kementerian terkait ini menjadi hambatan bagi para pengurus dan pimpinan Institusi Perguruan Tinggi baru, karena implikasi yang dihasilkan bersifat besar terhadap Institusi Perguruan Tinggi, khususnya bagi mahasiswa, lulusan dan pengguna lulusan (stakeholders).

Perhitungan secara kuantitatif dalam bobot $13,16 \%$ pada Kriteria 3 (tiga) Instrumen Akreditasi Perguruan Tinggi memiliki peran penilaian yang sangat penting. Dalam matriks penilaian yang diatur didalam Buku VI tentang Matriks Penilaian Borang dan Evaluasi Diri AIPT 2011 menjelaskan:

Tabel Deskriptor Penilaian Alumni

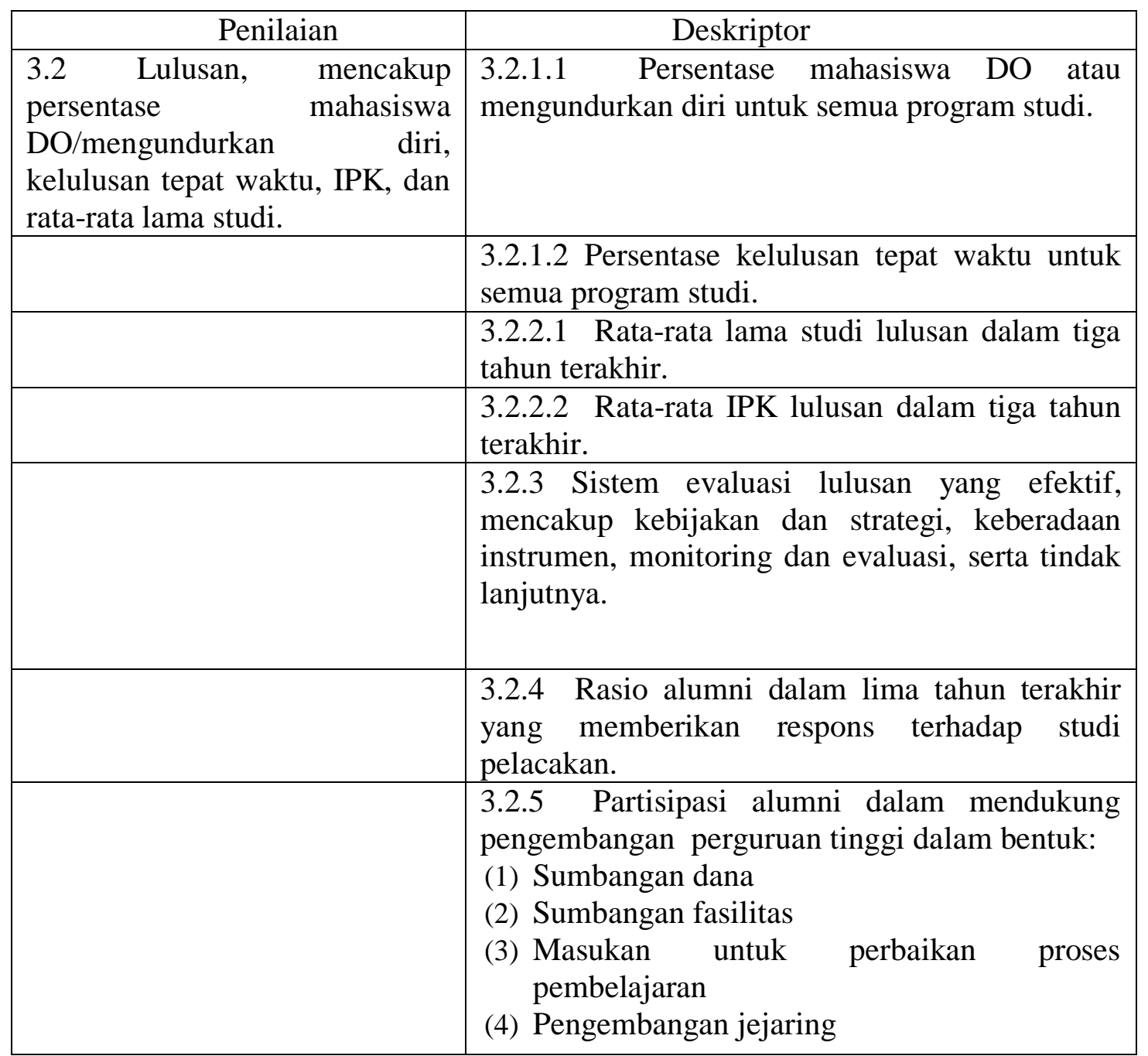

Deskriptor penilaian alumni pada matriks penilaian borang akreditasi dan evaluasi diri AIPT memiliki 5 (lima) harkat atau peringkat penilaian yaitu: 
1) Sangat Kurang $=0$

2) Kurang $=1$

3) Cukup $=2$

4) Baik $=3$

5) Sangat Baik $=4$

Sehingga didalam proses penetapan nilai akhir, jumlah 7 (deskriptor lulusan) x Nilai sangat baik (4) adalah 28 (dua puluh delapan) poin nilai yang pasti hilang / tidak bisa maksimal dari deskriptor penilaian pada Kriteria 3 (tiga) Mahasiswa dan Alumni.

Imbas yang dirasakan bagi Perguruan Tinggi Baru adalah dalam konteks dari sisi keadilan hukum. Karena faktor regulasi dalam penilaian maksimal akreditasi bagi Perguruan Tinggi Baru adalah Kebijakan Pemerintah yang mengatur tentang akreditasi itu sendiri. hal ini juga kontradiktif terhadap prinsip asas-asas umum pemerintahan yang baik (Good Govenance).

\section{PENUTUP}

\section{A. Kesimpulan}

Dalam proses akreditasi memuat Prinsip Independen, Akurat, Obyektif, Transparan, Akuntabel, sehingga Badan Akreditasi Nasional Perguruan Tinggi melaksanakan berdasarkan asas dan prinsip tersebut berdasarkan Peraturan PerundangUndangan namun didalam pelaksanaanya, kebijakan yang mengatur tentang akreditasi itu sendiri belum menjamin asas keadilan hukum yang menyeluruh.

Sesuai dengan asas umum pemerintahan yang baik (Good Governance) idealnya sebuah Kebijakan Publik dapat mencocoki asas kepastian, keadilan dan kemanfaatan hukum ditengah masyarakat. Namun pada kenyataanya implementasi dari pelaksanaan Akreditasi bagi Perguruan Tinggi Baru masih terkesan diskriminaitif dan belum mencerminkan asas keadilan.

Disatu sisi Perguruan Tinggi Baru juga harus mandiri dan berupaya menyesuaikan Sistem pendidikannya dengan SN Dikti, pada sisi lain Pemerintah dan BAN-PT perlu membuat formulasi aturan yang baru baik itu penambahan, perubahan/amandemen pada hilir regulasi akrediatasi Perguruan Tinggi. 


\section{B. Saran}

Salah satu upaya yang bisa dilakukan Pemerintah dan BAN-PT yaitu:

1. Memberikan standarisasi/kriteria penilaian yang khusus bagi Perguruan Tinggi Baru yang akan melaksanakan akreditasi;

2. Membuat parameter penilaian yang dapat dicapai dan memungkinkan bagi Perguruan Tinggi Baru;

3. Memberikan rekomendasi batasan waktu akreditasi ulang hingga Perguruan Tinggi Baru memenuhi komponen standar/kriteria akreditasi. 


\section{DAFTAR PUSTAKA}

\section{Buku}

Arifin Zainal (2009), Evaluasi pembelajaran, Bandung: Remaja Rosdakarya.

Buku I Naskah Akademik AIPT, (2011).

Buku III Borang AIPT, (2011).

Buku V Pedoman Penilaian Borang dan Evaluasi Diri Akreditasi Institus Perguruan Tinggi BAN-PT, (2011).

Dardji Darmohardjo, Shidarta,(2006) Pokok-pokok filsafat hukum: apa dan bagaimana filsafat hukum Indonesia, Jakarta: Gramedia Pustaka Utama.

Gunther Teubner, (2012) Subtantive and Reflexsive Elements in Modern Law, Law and Social Review, Volume 17 Nomor 2. Dikutip oleh Teguh Prasetyo dan Abdul Halim Barkatullah, Filsafat, Teori, dan Ilmu Hukum, Jakarta: Raja Grafindo.

Jimly Asshiddiqie (2006), Teori Hans Kelsen tentang Hukum, Sekretariat Jenderal Mahkamah Konstitusi, Jakarta.

John Rawls, (1971) A Theory of Justice, , Cambridge, Massachusetts, USA: Harvad University Press.

Ridwan HR, , (2014) Hukum Administrasi Negara, Jakarta: PT. Raja Grafindo Persada.

Said Sampara dkk, (2011), Pengantar Ilmu Hukum, Yogyakarta: Total Media.

\section{Peraturan Perundang-Undangan}

Undang-Undang Dasar Negara Republik Indoensia 1945.

Undang-Undang Nomor 20 Tahun 2003 tentang Sistem Pendidikan Nasional.

Undang-Undang Nomor. 12 Tahun 2012 tentang Pendidikan Tinggi.

Peraturan Pemerintah Nomor 19 Tahun 2005 tentang Standar Nasional Pendidikan.

Peraturan Pemerintah Nomor. 4 Tahun 2014 tentang Penyelenggaraan Pendidikan Tinggi dan Pengelolaan Institusi Perguruan Tinggi.

Peraturan Menteri Pendidikan dan Kebudayan Nomor 05 Tahun 2020 tentang Akreditasi Program Studi dan Institusi Perguruan Tinggi.

Peraturan BAN-PT Nomor 01 Tahun 2020 tentang Mekanisme Akreditasi Untuk Akreditasi yang Dilakukan oleh BAN-PT. 


\section{Jurnal}

Bahri, K., \& Rahmadiane, G.D., (2017), "Pengaruh Presepsi, Akreditasi Prodi, Dan Promosi Terhadap Keputusan Memilih Studi Akuntansi Pada Politeknik Harapan Bersama. Jurnal Inspirasi Bisnis dan Manajemen, Vol 1 (2), 145-158 Retrieved from Http://jurnal.unswagati.ac.id/index.php/jibm.

C. F. Sekarningsih, and A. Alamsyah, (2019), "Peranan Pengelolaan Arsip Sebagai Pendukung Akreditasi Ban-Pt Di Program Studi S-1 Pendidikan Biologi Fakultas Matematika Dan Ipa Univeristas Negeri Semarang (Studi Kasus Tahun 2015)", Jurnal Ilmu Perpustakaan, Vol. 6 (3), 421-430.

Nuphus F.N.. A Rahmatulloh, (2019), "Sistem Informasi Akreditasi Perguruan Tinggi (SIAP) untuk Pengisian Borang Standar 3 BAN-PT)", Jurnal Sistem dan Teknlogi Informasi, Vol. 2, 130-137.

Prasetyo, H. (2014), "Dampak Kebijakan Akreditasi Perguruan Tinggi Terhadap Daya Saing (Competitiveness) Perguruan Tinggi Swasta Di Kabupaten Kebumen", Jurnal Fokus Bisnis: Media Pengkajian Manajemen Dan Akuntansi, Vol 13 (1), 31-47 https://doi.org/10.32639/fokusbisnis.v13i1.13

Ridwansyah M, (2016), "Mewujudkan Keadilan, Kepastian dan Kemanfaatan Hukum dalam Qanun Bendera dan Lambang Aceh”, Jurnal Konstitusi, Vol. 13 (2), 278-298.

Sulardi, (2015), "Kepastian Hukum, Kemanfaatan dan Keadilan Terhadap Perkara Pidana Anak (Kajian Putusan Nomor 201/Pid.Sus/2014/PN/Bly)", Jurnal Yudisial, Vol. 8 (3), 251-268.

Sururin, (2017), "Peta Peringkat Akreditasi Perguruan Tinggi Keagamaan Islam. Sebuah kajian awal", Jurnal At-Taqaddum, Vol 9 (1), 95-112.

Suwardi Sagama, (2016), “Analisis Konsep Keadilan, Kepastian Hukum Dan Kemanfaatan Dalam Pengelolaan Lingkungan”, Jurnal Pemikiran Hukum Islam, Vol 15 (1), 2041.

Yulianingsih Y, (2015), "Manajemen Akreditasi Program Studi Pada Perguruan Tinggi”, AlIdarah: Jurnal Kependidikan Islam, Vol. 5 (1), 92-116.

\section{Internet}

KBBI, http://kbbi.web.id/manfaat

Rijal09 (2016), Pengertian Evaluasi, Penilaian dan Tes, http://www.rijal09.com/2016/03/vbehavioururldefau ltvmlo_28.html?m=1 